\title{
Reduction of Ascaridia galli Pathology by Salmonella typhimurium in Broiler Chicken
}

\author{
Eric Igor Sop Foka $\mathbb{D}^{1}$ Cedric Yamssi ${ }^{1},{ }^{2}$ Ben Enyetornye, ${ }^{3}$ \\ Christelle Noumedem Anangmo $\mathbb{D}^{4},{ }^{4}$ Mpoame Mbida, ${ }^{1}$ and Theodore B. Mayaka ${ }^{1}$ \\ ${ }^{1}$ Department of Animal Biology, Faculty of Sciences, University of Dschang, Cameroon \\ ${ }^{2}$ Department of Biomedical Sciences, Faculty of Health Sciences, University of Bamenda, Cameroon \\ ${ }^{3}$ School of Veterinary Medicine, University of Ghana, Legon, P.O. Box LG 139, Accra, Ghana \\ ${ }^{4}$ Department of Microbiology, Hematology and Immunology Faculty of Medicine and Pharmaceutical Sciences, \\ University of Dschang, Cameroon
}

Correspondence should be addressed to Eric Igor Sop Foka; ericigor2006@yahoo.fr

Received 4 May 2021; Revised 14 August 2021; Accepted 24 August 2021; Published 6 September 2021

Academic Editor: José F. Silveira

Copyright (c) 2021 Eric Igor Sop Foka et al. This is an open access article distributed under the Creative Commons Attribution License, which permits unrestricted use, distribution, and reproduction in any medium, provided the original work is properly cited.

\begin{abstract}
Previous studies have reported interactions between Salmonella spp. and some helminth coinfections. In this study, S. typhimurium and Ascaridia galli coinfections were analyzed, and the consequences on therapy were proposed. In a first experiment where the effect of the bacteria on the nematode was evaluated, thirty 42-day-old broiler chickens were divided into 3 groups and coinfected with both parasites. The rate of A. galli egg inoculum was kept constant at 500/ml while that of S. typhimurium varied as follows: $\mathrm{T}_{0}(500$ A. galli eggs $/ \mathrm{ml}), \mathrm{T}_{104}(500$ A. galli eggs $/ \mathrm{ml}+104$ S. typhimurium CFUs), and $\mathrm{T}_{106}\left(500\right.$ A. galli eggs $/ \mathrm{ml}+10^{6} \mathrm{~S}$. typhymurium CFUs). EPG and parasitic load were measured using the McMaster technic, and number of worms and their length were also measured. We observed that $\mathrm{T}_{106}$ containing $10^{6}$ CFUs of Salmonella significantly reduced the EPG values, and this group recorded the lowest worm load ranging from 18 to 21 worms. Likewise, the length of the worms obtained with $\mathrm{T}_{104}$ and $\mathrm{T}_{106}$ appeared to be shorter than those of the control $\left(\mathrm{T}_{0}\right)$. In a second experiment to assess the effects of the nematode on the bacteria, thirty 42-day-old broiler chickens were divided into 3 groups and coinfected with both parasites. The rate of S. typhimurium inoculum was kept constant at $10^{6}$ CFUs while that of $A$. galli varied as follows: $\mathrm{T}_{0}\left(10^{6} \mathrm{CFUs}\right), \mathrm{T}_{500}\left(500\right.$ A. galli eggs/ml $+10^{6} \mathrm{~S}$. typhymurium CFUs), and $\mathrm{T}_{750}$ (750 A. galli eggs $/ \mathrm{ml}+10^{6} \mathrm{~S}$. typhymurium CFUs). Bacterial load was measured using Voogt technique. We observed that $\mathrm{T}_{500}$ increased the colonization time and prolonged the duration of $S$. typhimurium secretion. Salmonella appears to be a hyperparasite considering the deleterious effect on A. galli. Due to this, it may be prudent to combine anti-Salmonella treatment with anthelmintic so as to effectively treat pathologies caused by these two pathogens.
\end{abstract}

\section{Introduction}

The study of the interaction between Gram-negative bacteria and parasites dates back to decades where [1] suggested Strongyloides can drag Escherichia coli during their migration from the intestine to other organs of the host. Other nematodes such as Trichinella spiralis and A. galli have been identified as direct vectors for Salmonella transmission [2,3]. Laboratory studies on schistosomes showed that Salmonella can colonize the intestinal tract of Schistosoma mansoni [4]. [5] demon- strated the association of Salmonella and schistosomes by culturing Salmonella paratyphi from certain schistosomes. Several experimental studies have begun to demonstrate the persistence and enhanced growth of Salmonella in chickens concurrently infected with Ascaridia galli [6]. In this regard, the presence of $A$. galli worms in vivo indicates that chickens were infected transiently with Salmonella typhimurium. The identification of Salmonella organisms within the gut or on the tegument of $A$. galli worms further indicated an intimate association between these two pathogens [7]. This study 
provides a baseline for the understanding of the frequently noted clinical signs associated with chronic salmonellosis in chickens [8].

Several studies have shown the major importance of the association between these bacteria (S. typhimurium) and the helminth (A. galli). These studies focused not only on the pathogenic effects on the host but also the consequences in terms of therapy [9] as these pathogens represent a real problem for both avian and human health. This led to integration of measures complying with the One Health $(\mathrm{OH})$ approach of disease prevention and control. In order to ensure food security and safety, the tripartite alliance of WHO-FAO and OIE emphasised the need to curb the spread of these pathogens between and among animal and humans [10]. The threat of these pathogens is that they cause zoonoses which is linked to the consumption of poultry meat or products. Research findings of [6] revealed that A. galli could play a major role in the transmission of Salmonella infections, consequently increasing the economic losses in the agro-pastoral sectors. The total cost losses are estimated to be between 15.5 million USD to 2.8 billion dollars yearly in the United States of America [11].

The clinical manifestation of salmonellosis alone seems to differ significantly from situations of coinfection. In the case of schistosomes [12] and A. galli [13], the treatment of salmonellosis becomes difficult or even impossible when it is associated with schistosomes [9]. The transmission of the bacteria can be done by A. galli eggs [13] indicating a possible interaction between them. However, there is paucity of information on these interactions especially one involving A. galli. A better understanding of these interactions could help explain the pathologies caused by these two parasites. This study was undertaken to explore the interactions that could exist between Salmonella typhimurium and A. galli as well as predict the implications for therapy.

\section{Material and Methods}

2.1. Study Location. The study was conducted in the Biology and Applied Ecology laboratory and in the Physiology and Animal Health laboratory of the University of Dschang, Cameroon.

Experimental animals: The broiler chickens (Abor acres) breed used in this study were obtained from commercial poultry supplier (Cameroon Provender Company) based in Dschang, Cameroon.

2.2. Source of S. typhimurium. Salmonella sample were supplied by Professor LoVerde Philip of the University of Texas Health, USA.

2.3. Source of A. galli Eggs and Infection. Local chickens naturally infected with A. galli were humanely euthanized. Adult worms were recovered from their intestines and rinsed twice in phosphate-buffered saline (PBS, pH: 7.2). Their eggs were removed from worms' uteri and then incubated for 21 days in $0.1 \mathrm{~N}$ sulfuric acid to obtain embryonated eggs [14]. After egg embryonation, chickens previously raised up to 42 days were infected with A. galli eggs. Chickens were sacrificed 30 days postinfection, and the adult worms were removed from the intestines.

2.4. Experiment 1: Effects of S. typhimurium on A. galli Coinfection on the Hosts. For the evaluation of the bacteria effect on the nematode, thirty 42-day-old "Arbor acres" breed of broiler chickens was divided into 3 equal groups as described by [6] but with little modification and coinfected with both parasites. The rate of A. galli egg inoculum was kept constant at $500 / \mathrm{ml}$ while that of $S$. typhimurium varied as follows: $\mathrm{T}_{0}, \mathrm{~T}_{104}$, and $\mathrm{T}_{106}$ (Table 1). On the $30^{\text {th }}$ day postinoculation, parameters such as EPG, parasitic load, and length of worms were measured.

2.5. Concentration of Fecal Egg (EPG). To determine the EPG, stool samples were taken on daily basis in all experimental groups for 21 days. The samples were stored in $10 \%$ formalin and then examined qualitatively (flotation technique) to confirm infection and quantitatively (Mc Master technique) to determine the EPG. Two grams (2g) of stool samples were mixed with $60 \mathrm{ml}$ of saturated saline solution ( $400 \mathrm{~g}$ of $\mathrm{NaCl}$ in 1liter of distilled water). Since the stool samples were preserved in formalin, it was difficult to extract $2 \mathrm{~g}$ of stool from the mixture, so the total weight (MT) of every flask containing stool sample, the weight of $10 \mathrm{ml}$ of formalin $\left(m_{1}\right)$, and the empty flask weight $(m t)$ were measured, respectively. The exact stool weight $(\mathrm{mmf})$ within each flask was then determined by the following formula: $\mathrm{mmf}=\mathrm{MT}-\left(m_{1}+\mathrm{mt}\right)$.

The proportion of stool percentage within every flask (\% mmf) was obtained by using the formula $\% \mathrm{mmf}=$ $\mathrm{mmf} \times 100 /\left(\mathrm{mmf}+m_{1}\right)$.

To deduct of the stool-formalin mixture $(Y g)$ and to determine $X g$ with the formula $\mathrm{Xg}=\% \mathrm{mmf} \times \mathrm{Yg}, X g$ was determined using Willis and Mc Master techniques.

2.6. Parasitic Load and Measurement of Parasite Length. Chickens were euthanized 52 days postinfection. Adult worms and larvae were then extracted from the intestine. After extraction of the worms, females were separated from the males by observing the posterior parts using a Pierron ${ }^{\circledR}$ brand binocular loop. The length of each worm was measured using a graduated ruler to identify stunted worms.

2.7. Experiment 2: Effects of A. galli on S. typhimurium Coinfection on the Hosts. For the evaluation of the nematode effect on Salmonella typhimurium, thirty 42-day-old "Arbor acres" breed of broiler chickens was also divided into 3 equal groups and coinfected with both parasites. The rate of $S$. typhimurium inoculum was kept constant at $10^{6} \mathrm{CFUs}$ while that of A. galli varied as follows: $\mathrm{T}_{0}\left(10^{6} \mathrm{CFUs}\right), \mathrm{T}_{500}$, and $\mathrm{T}_{750}$ (Table 2). The bacterial load was monitored at 3 days interval for 21 days postinfection. Cloacal swabs were taken to measure bacterial load as described by [15]. The solutions obtained were incubated on Salmonella-Shigella agar at $37^{\circ} \mathrm{C}$ for 24 to $48 \mathrm{~h}$ to enumerate the Salmonella colonies.

2.8. Statistical Data Analysis. Statistical analyses were done using the R software, version 3.5.3 of [16], mainly for categorical analyzes [17], in R. To gain a better understanding 
TABle 1: Experimental design-1.

\begin{tabular}{lcccc}
\hline No. & Group size & Experimental groups & A. galli inoculum eggs & Salmonella typhimurium/CFUs \\
\hline $\mathrm{T}_{0}$ & 10 & A. galli & 500 & 0 \\
$\mathrm{~T}_{104}$ & 10 & A. galli + Salmonella typhimurium & 500 & $10^{4}$ \\
$\mathrm{~T}_{106}$ & 10 & A. galli + Salmonella typhimurium & 500 & $10^{6}$ \\
\hline
\end{tabular}

TABLE 2: Experimental design-2.

\begin{tabular}{lcccc}
\hline No. & Group size & Experimental groups & A.galli inoculum eggs/ml & Salmonella typhimurium CFUs \\
\hline $\mathrm{T}_{0}$ & 10 & S. typhimurium & 0 & $10^{6}$ \\
$\mathrm{~T}_{500}$ & 10 & A. galli + S. typhimurium & 500 & $10^{6}$ \\
$\mathrm{~T}_{750}$ & 10 & A. galli + S. typhimurium & 750 & $10^{6}$ \\
\hline
\end{tabular}

of the effects of Salmonella on the nematode, the frequencies of reported EPG means were tested by Satterthwaite's $t$-test, while those of the length of A. galli worms were assessed through the Shapiro-Wilk Normality Test. Furthermore, the effects of nematode on bacteria were examined by applying nonparametric polynomial regression to differentiate the means of the logarithm of the bacterial load. All tests were performed at $5 \%$ probability level.

\section{Results}

3.1. Experiment 1: Effects of S. typhimurium on A. galli Coinfection on the Hosts. Figure 1 shows variations in EPG in the three treatments. The raw data on the EPGs were transformed to produce normally distributed data. Positive fecal egg counts were detected; the first-time individual samples were taken. EPGs varied over time with a bell-shaped structure and a peak occurring around the $12^{\text {th }}$ day. There is also a variation in EPGs based on the treatments. The lowest values were obtained with $\mathrm{T}_{106}$ while the highest values were recorded with $\mathrm{T}_{0}$. In addition, the duration of $A$. galli excretion with the same treatment was relatively shorter than those of the other groups. $\mathrm{T}_{106}$ containing $10^{6}$ CFUs of Salmonella significantly reduced the EPG values. $\mathrm{T}_{104}$ produced intermediate effects in comparison with the control and $\mathrm{T}_{106}$.

The parabolic regression analysis showed that the intercept, the linear, and the quadratic terms were highly significant over time. Thus, EPGs of the three concentrations of Salmonella typhimurium differ significantly $(P<0.05)$ from each other. The significant differences between the concentrations of Salmonella typhimurium can clearly be observed from the following parabolic regression equations:

$$
\begin{aligned}
& {\left[\mathrm{T}_{0}\right] \beta_{0}:-0.624+0.835 t-0.0335 t^{2},} \\
& {\left[\mathrm{~T}_{104}\right] \beta_{1}:-0.624+0.809 t-0.035 t^{2},} \\
& {\left[\mathrm{~T}_{106}\right] \beta_{1}:-0.624+0.726-0.0315 t^{2} .}
\end{aligned}
$$

3.2. Effect of Salmonella typhimurium on Parasitic Load. Occasionally, expelled worms have been found in the feces of the birds during the experimental period. The number of worms recorded at postmortem at the end of the experi-

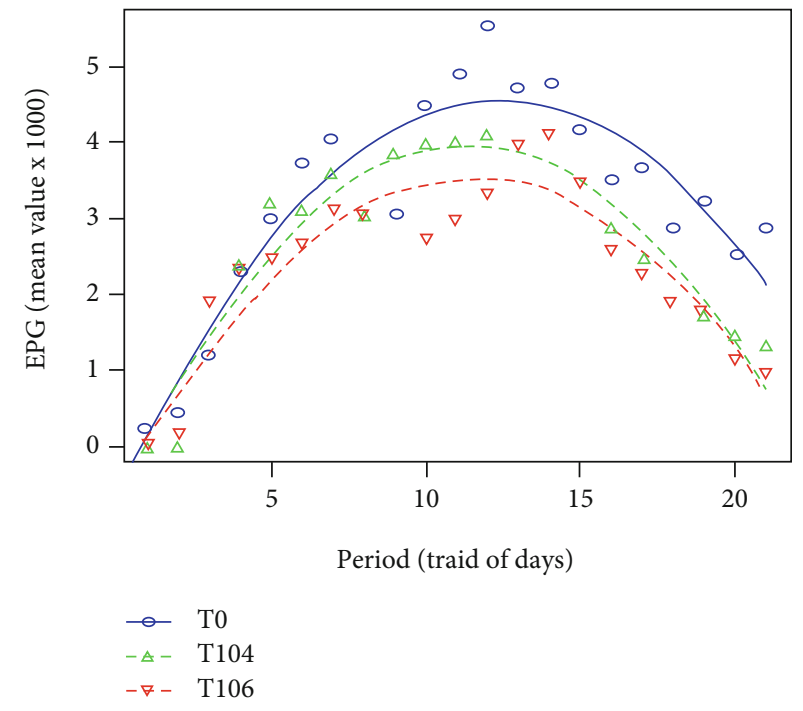

FIgUre 1: Ascaridia galli fecal eggs (EPG) according to Salmonella typhimurium concentrations and time. $\mathrm{T}_{0}$ : concentration $500 \mathrm{~A}$. galli ova +0CFUs of Salmonella typhimurium; $\mathrm{T}_{104}: 500$ A. galli ova $+10^{4}$ CFUs Salmonella typhimurium; $\mathrm{T}_{106}: 500$ A. galli ova $+10^{6}$ CFUs of Salmonella typhimurium.

ments is shown in the boxplots (Figure 2). There was great variability in the number of worms per host in the different groups. No other gastrointestinal parasites except A. galli were seen at postmortem. The distribution of worms in each boxplot is divided into four equal areas (25\%). From these boxplots (Figure 2), the median was 28 worms in $\mathrm{T}_{0}$. In the same group, birds with lowest worm load were recorded between 20 and 23 worms while the highest worm load was between 32 and 40 worms. $\mathrm{T}_{106}$ group recorded the lowest worm load ranging from 18 to 21 worms. At $10^{4}$ CFUs, worm's median was 27 worms, and the lowest worm load was between 28 and 35 worms. Analysis of the general linear model showed that the parasitic load obtained with $\mathrm{T}_{0}$ (Table 2) significantly differed from the other concentrations $(P<0.001)$. There was no significant difference between the parasitic loads obtained with double parasitism $\left(\mathrm{T}_{104}\right.$ and $\mathrm{T}_{106}$ ) although $10^{6}$ CFUs (Table 2) of S. typhimurium 


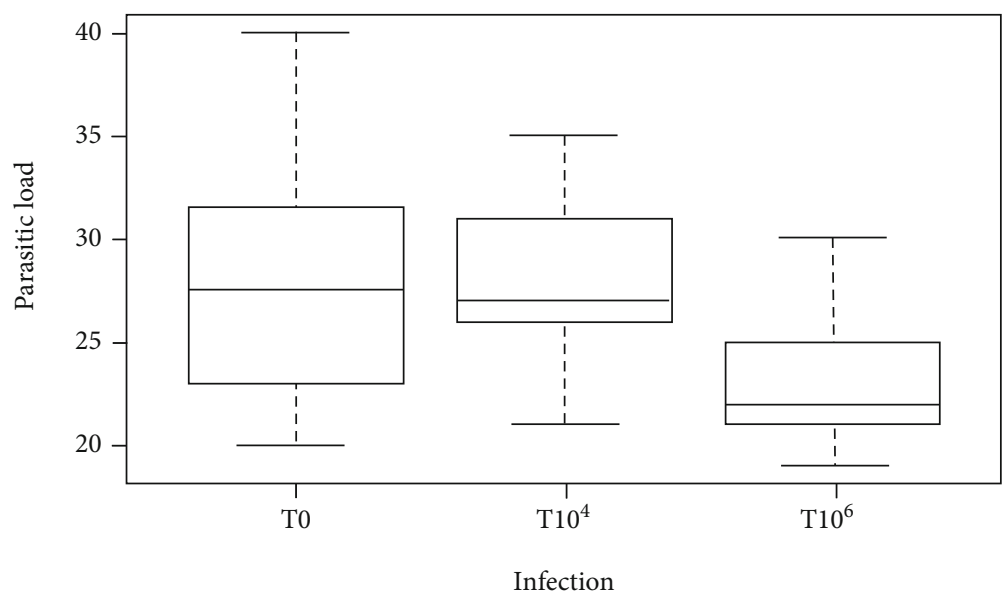

FIgURe 2: Ascaridia galli parasitic load in infective host groups with varying Salmonella typhimurium concentration. $\mathrm{T}_{0}$ : concentration 500 of A. galli+0CFUs Salmonella typhimurium; $\mathrm{T}_{104}$ : concentration 500 A. galli+104 CFUs Salmonella typhimurium; $\mathrm{T}_{106}:$ concentration 500 A. galli+106 CFUs de Salmonella typhimurium.

reduced the number of worms (larvae + adults) considerably. The effect of monoparasitism was not to double parasitism $(P<0.05)$.

3.3. Effect of Salmonella typhimurium on the Length of Ascaridia galli Worms. The variation in length of A. galli as a function of treatments is presented in Figure 3. From this figure, the median of the length of the worms was $52 \mathrm{~mm}$ in the control group $\left(\mathrm{T}_{0}\right)$. In the same group, the medium-sized worms recorded were between 42 and $63 \mathrm{~mm}$ while the highest size worm was between 63 and $83 \mathrm{~mm}$ worms. In $\mathrm{T}_{104}$ and $\mathrm{T}_{106}$, the medians were 42 and $45 \mathrm{~mm}$, respectively. The maximum length of worms in these groups $\left(\mathrm{T}_{104}\right.$ and $\left.\mathrm{T}_{106}\right)$ were 60 and $62 \mathrm{~mm}$, respectively. The Shapiro-Wilk normality test showed that there was a gender effect on worms' length. It was observed from this test that male worms were significantly shorter than female worms $(P=0.005)$. There was a significant $(0.05)$ length reduction in worms from birds in $\mathrm{T}_{106}$ group compared with the controls. There was no significant $(P>0.05)$ difference between the interaction of treatments on sex. Likewise, the length of the worms obtained with $\mathrm{T}_{104}$ appeared to be shorter than those of the control, but not statistically significantly $(P=0.465)$. However, the length obtained with the $\mathrm{T}_{106}$ was significantly shorter than those of the control $(P=0.01)$.

3.4. Experiment 2: Effects of A. galli on S. typhimurium Coinfection on the Hosts. The variation of the bacterial load over time is shown in Figure 4. The bacterial load varied depending on the concentration of the inoculum. We have observed two bell curves $\left(\mathrm{T}_{0}\right.$ and $\left.\mathrm{T}_{500}\right)$ and an inverted sigmoid $\left(\mathrm{T}_{750}\right)$. The highest bacterial load was recorded with the $\mathrm{T}_{0}$ (Table 2) inoculum, with a maximum value occurring on the $11^{\text {th }}$ day. However, the duration of excretion of the bacteria in $\mathrm{T}_{0}$ remained relatively short. With the $\mathrm{T}_{750}$ inoculum, the bacterial load was less but with a prolonged duration of secretion as seen in Figure 4. The bacterial load at the $\mathrm{T}_{500}$ concentration was slightly higher than the one obtained

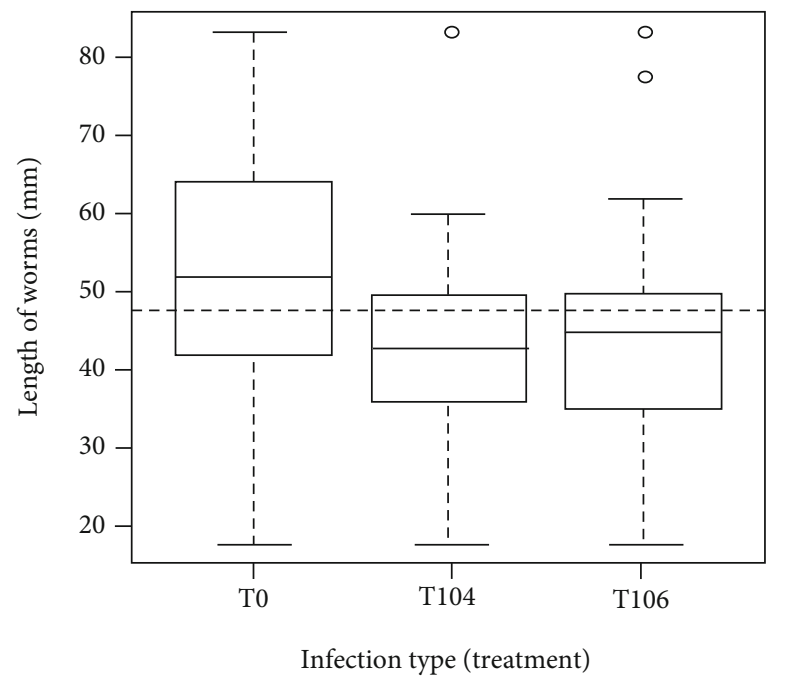

FIgURE 3: Effect of Salmonella typhimurium on Ascaridia galli worm's length. $\mathrm{T}_{0}$ : concentration 500 worm ova A. galli+0CFUs Salmonella typhimurium; $\mathrm{T}_{104}$ : concentration 500 A. galli+104 CFUs Salmonella typhimurium; $\mathrm{T}_{106}$ : concentration 500 A. galli +106 CFUs Salmonella typhimurium.

with $\mathrm{T}_{750}$. The analysis of the nonparametric polynomial regression showed that the values of the bacterial load obtained with the inoculum $\mathrm{T}_{0}$ differed significantly from the other concentrations $(P<0.001)$. Moreover, the bacterial load varied significantly from one group to another $(P<0.05)$. Thus, A. galli prolonged the duration of Salmonella typhimurium secretion.

\section{Discussion}

Considering that A. galli egg excretion was higher in the control group than those in the coinfected group, it suggests that the best method for the detection of A. galli perhaps is the manual count of eggs in the stool. Only mature female worms laid eggs, and the diagnosis is only possible after a 


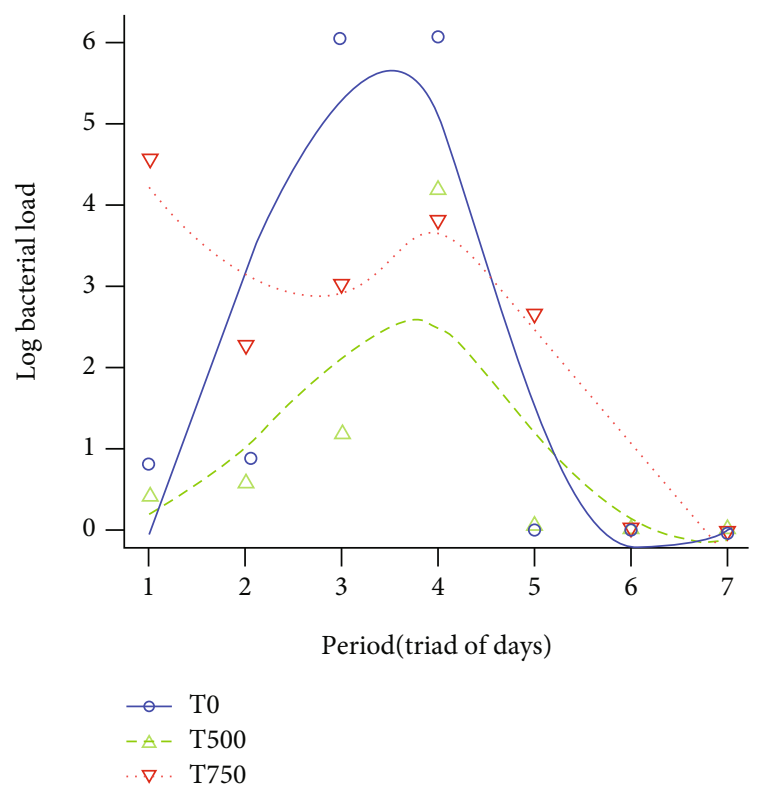

FIgURE 4: Bacterial load after oral inoculation of broiler chicken with Salmonella typhimurium. $\mathrm{T}_{0}$ : concentration $10^{6}$ CFUs de Salmonella typhimurium +0 A. galli; $\mathrm{T}_{500}$ : concentration $10^{6}$ CFUs de Salmonella typhimurium +500 A. galli; $\mathrm{T}_{750}$ : concentration $10^{6}$ CFUs de Salmonella typhimurium +750 A. galli.

heavy infection. In addition, Salmonella infected reproductive tissues and cause ovarian and testicular abscesses, which affects egg formation and drastically reduces parasite's egglaying rate [18]. Testicular abscesses cause the inhibition of ascaroside secretion by male worms. Nematodes secrete ascarosides as pheromones to induce egg formation as well as to control various behavior including female attraction to males and adult aggregation $[19,20]$.

Parasites generally show high reproductive potential which is responsible for exponential growth in numbers, which is a characteristic of microorganisms. Egg production is often high when we consider the daily laying rate and the parasite longevity. In the case of Ascaris, it lays about 200,000 eggs per day, with a life span of nine months [21]. It may therefore be reasonable to expect a higher A. galli egg excretion in the coinfected group, since these two parasites occupy the same niche within hen's intestine [22]. This study demonstrated that $S$. typhimurium may play an important role in reducing the egg laying ability of $A$. galli, as the values of EPG obtained in coinfected groups were lower than those in the control. This could be explained by the ability of the bacteria to infect reproductive tissues like the oviduct and the ovaries. These tissues serve as a gate way for the contamination of eggs in hens $[18,23]$.

It is generally accepted that the establishment of $A$. galli in chicken intestine is influenced by many factors such as age, infectious dose, sex, and the host diet. A report by [4] using various bacterial species found that certain species of bacteria, including Klebsiella sp. and Escherichia coli, rapidly colonize Schistosoma mansoni and subsequently lead to the death of the worms. These authors further indicated that $S$. typhimurium naturally present in mice infected with $S$. man- soni causes the death of all the worms. The length of the worms extracted inside the control group was bigger in size than those extracted from the coinfected groups. It is possible that the expulsion of the worms had some impacts on the average load of the worms. This difference in size and parasitic load observed can be a consequence of competition for space and nutrients because the two pathogens (Salmonella and A. galli) occupy the same site which is the intestine. These pathogens must also find a balance in order to keep the host alive, as death of the host will eventually lead to parasite's death. Male worms outnumbered female worms in all the experimental groups. This phenomenon allows each adult female worm to have at least one male for mating in order to lay fertile eggs, to ensure the survival of the species [21]. The number of eggs that a female worm can lay also explains the fecal egg concentration obtained in this study. The likelihood of A. galli establishing infection has been shown to be significantly higher in chickens [6].

The specific effects of Salmonella on the integrity and viability of worms have not been reported in other studies. Based on the findings from this study, it is obvious that Salmonella has variable effects on A. galli including the reduction of growth, laying rate, and death of worms. The average bacterial load follows the Gaussian curve. The decrease of the bacterial load in coinfected groups is due to interspecific competition. The value of the bacterial load was greater in the control group, but the duration of excretion of these bacteria was longer in the coinfected groups. Salmonella excretion is believed to be favored by A. galli when $S$. typhimurium is found in the digestive tract and uterus of A. galli [7] Competing infections with A. galli and other bacteria have shown that $A$. galli facilitates bacterial infections [23] This may be related to the polarization of the immune response; the immune response of mammals is known to polarize in type 1 (Th1) or type 2 (Th2) immune pathways depending on the type of pathogen encountered [24]. Similar findings have been reported by [25] in chickens. Thus, helminth infection could suppress the Th1 response and indirectly favor the establishment of bacterial infection and vice versa. Dendritic cells stimulated by helminth infections play an important role in the regulation of the intestinal immune response as well as in the modulation of bacterial pathogenesis as described in [26] This is because helminth infections alter host's response to competing bacterial infections and promote bacterial intestinal binding via a novel mechanism that requires activation of dendritic cells and expression of interleukins-10 (IL-10) [26].

These results further provide plausible reasons for the difficulty of antimicrobial therapy in both natural infections with Salmonella when there is coinfection with Ascaridia spp. in chicken and even in experimental models. Some researcher suggested that the treatment of salmonellosis can be achieved by simply deworming the host, thus suggesting the dependence of the bacteria on the presence of live worms in vivo [27]. Moreover, other researchers reported that parasitic helminths are linked to a number of changes in host's organs, which facilitate Salmonella infections [28, 29]. However, the potential variability of host cell interactions continues to complicate the understanding of the 
response of A. gallus to S. typhimurium infections [8]. [29] compared five serovars of Salmonella that infect poultry ( $S$. typhimurium, S. enteritidis, S. Heidelberg, S. Kentucky, and $S$. Senftenberg) so as to assess cell invasion by Salmonella, its intracellular survival mechanisms, modulation of phorbol myristate acetate (PMA), and burst oxidative activity of nitric oxide in a chicken macrophage cell line transformed by the MC29 virus and HD-11 were evaluated. Salmonella enteritidis and $S$. typhimurium did not generate any detectable production of nitric oxide [29]. In addition, the complexity of the interaction between the microflora of the gastrointestinal tract, the immune system, and hostdependent factors such as age, stress level, and general health may play an important role in host-pathogen interactions and the reduction of Salmonella excretion [30, 31] The increased susceptibility to entero-pathogens of bacterial origin by helminth infections could contribute to failure of the use of Salmonella vaccines in countries with high helminth prevalence, since helminths modulate the immune response against Salmonella-based vaccines [32].

\section{Conclusion}

Salmonella typhimurium has deleterious effects on A. galli by reducing the nematode length and load in broiler chickens. This is in agreement with other studies that demonstrated that Salmonella interacts with gastrointestinal nematodes when they live together in a common environment. Moreover, the effects of this interaction between S. typhimurium and A. galli have been shown to be harmful both for the $A$. galli. This is manifested in the reduction in pathogenicity of A. galli. In view of these bacteria, deleterious effect on A. galli and Salmonella appears to be a hyperparasite. It would be wise to recommend the association of anti-Salmonella treatment with anthelmintic for the treatment of pathologies caused by these two pathogens. This needs to be considered in the future to augment other control strategies in poultry.

\section{Data Availability}

The datasets generated and analysed in the current study can be made available by the corresponding author upon reasonable request.

\section{Ethical Approval}

All authors of this work hereby declare that the guidelines for ethical conduct in the care and use of nonhuman animals in research were followed as well as specific national laws pertaining to animal use and care. All experiments have been examined and approved by the appropriate ethics committee.

\section{Conflicts of Interest}

The authors declare no competing interests.

\section{Acknowledgments}

The authors gratefully acknowledge LoVerde Philip (University of Texas Health, San Antonio, USA) for kindly providing Salmonella typhimurium $\mathrm{LT}_{2}-1344$. We are very thankful to Katte Bridget for the technical assistance.

\section{References}

[1] J. A. Walker-Smith, B. McMillan, A. W. Middleton, S. Robertson, and A. Hopcroft, "Strongyloidiasis causing small-bowel obstruction in an Aboriginal infant," Medical Journal of Australia, vol. 2, no. 25, pp. 1263-1265, 1969.

[2] R. Spaldonova, O. Tomasovicova, Z. Koppel, and D. Duwel, "Trichinella spiralis as the carrier of Salmonella typhimurium," Zentralbl. Bakteriology., vol. 211, pp. 47-52, 1969.

[3] C. Dahl, A. Permin, J. P. Christensen et al., "The effect of concurrent infections with Pasteurella multociida and Ascaridia galli on free-range chickens," Veterinary Microbiology, vol. 86, pp. 313-324, 2002.

[4] H. Ottens and G. Dickerson, "Studies on the effects of bacteria on experimental schistosome infections in animals," Transactions of the Royal Society of Tropical Medicine and Hygiene, vol. 66, no. 1, pp. 85-107, 1972.

[5] S. W. Young, G. Higashi, R. Kamel, A. Z. el Abdin, and I. A. Mikhail, "Interaction of salmonellae and schistosomes in host-parasite relations," Transactions of the Royal Society of Tropical Medicine \& Hygiene, vol. 67, no. 6, pp. 797-802, 1973.

[6] N. M. Eigaard, T. W. Schou, A. Permin et al., "Infection and excretion of Salmonella enteritidis in two different chicken lines with concurrent Ascaridia galli infection," Avian Pathology, vol. 35, no. 6, pp. 487-493, 2006.

[7] E. I. Sop Foka, J. Yondo, L. Agyingi, H. G. Tsila, and M. Mbida, "Transport capacity of Salmonella typhimurium by Ascaridia galli body parts," International Journal of Science and Research, vol. 8, pp. 768-770, 2019.

[8] S. L. Foley, T. J. Johnson, S. C. Ricke, R. Nayak, and J. Danzeisen, "Salmonella pathogenicity and host adaptation in chicken-associated serovars," Microbiology and Molecular Biology Reviews, vol. 77, no. 4, pp. 582-607, 2013.

[9] E. A. Barnhill, E. Novozhilova, T. A. Day, and S. A. Carlson, "Schistosoma-associated Salmonella resist antibiotics via specific fimbrial attachments to the flatworm," Journal of Parasites and Vectors, vol. 4, pp. 123-131, 2011.

[10] L. L. Founou, R. C. Founou, and S. Y. Essack, "Antibiotic resistance in the food chain: a developing country-perspective," Frontiers in Microbiology, vol. 7, p. 1881, 2016.

[11] S. Hoffman, B. Maculloch, and M. Batz, Economic burden of major foodborne illness acquired in the United States. A report summary from the Economic Research Service, United States Department of Agriculture, (no. 1476-2016-120935), 2015.

[12] P. T. LoVerde, C. Amento, and G. I. Higashi, "Parasite-parasite interaction of Salmonella typhimurium and Schistosoma," Journal of Infectious Diseases, vol. 41, pp. 177-185, 1980.

[13] M. Chadfield, A. Permin, P. Nansen, and M. Bisgaard, "Investigation of the parasitic nematode Ascaridia galli (Shrank 1788) as a potential vector for Salmonella enterica dissemination in poultry," Parasitology Research, vol. 87, pp. 317-325, 2001.

[14] A. Permin, M. Pearman, P. Nansen, M. Bisgarrd, and F. Frandsen, "An investigation on different media for 
embryonation of Ascaridia galli eggs," Helminthologia, vol. 34, pp. 75-79, 1997.

[15] N. Voogt, M. Raes, W. J. B. Wannet, A. W. Henken, and A. W. van de Giessen, "Comparison of selective enrichment media for the detection of Salmonella in poultry faeces," Letters in Applied Microbiology, vol. 32, no. 2, pp. 89-92, 2001.

[16] R Development Core Team R, A language and environment for statistical computing, R Foundation for Statistical Computing, Vienna, Austria, 2007, http://www.r-project.Org.

[17] A. Agresti, Categorical Data Analysis, John Wiley \& Sons Interscience, New-York, USA, Second edition, 2002.

[18] J. De Vylder, R. Raspoet, J. Dewulf, F. Haesebrouck, R. Ducatelle, and F. Van Immerseel, "Salmonella Enteritidis is superior in egg white survival compared with other Salmoella serotypes," Poultry Sciences, vol. 92, pp. 842-845, 2013.

[19] Y. Izrayelit, J. Srinivasan, S. L. Campbell et al., "Targeted metabolomics reveals a male pheromone and sex-specific ascaroside biosynthesis in Caenorhabditis elegans," ACS Chemical Biology, vol. 7, no. 8, pp. 1321-1325, 2012.

[20] Y. Zhou, Y. Wang, X. Zhang et al., "Biosynthetic tailoring of existing ascaroside pheromones alter their biological function in Caenorhabditis elegans," Elife Biochemistry and Chemical Biology, vol. 33, pp. 1-21, 2018.

[21] E. J. L. Soulsby, Helminths, Arthropods and Protozoa of Domesticated Animals, Baillere, Tindal, London, 7th edition, 1982.

[22] I. Gantois, R. Ducatelle, F. Pasmans, F. Haesebrouck, and F. Van Immerseel, "The Salmonella enteritidis lipopolysaccharide biosynthesis gene $\mathrm{rfbH}$ is required for survival in egg albumen," Zoonoses and Public Health, vol. 56, pp. 145-149, 2009.

[23] A. Permin, J. P. Christensen, and M. Bisgaard, "Consequences of concurrent Ascaridia galli and Escherichia coli infections in chickens," Acta Veterinaria Scandinavica, vol. 47, pp. 43-54, 2006.

[24] F. E. Cox, "Concomitant infections, parasites and immune responses," Parasitology, vol. 122, pp. S23-S38, 2001.

[25] W. G. Degen, N. Daal, L. Rothwell, P. Kaiser, and V. E. Schijns, "Th1/Th2 polarization by viral and helminth infection in birds," Veterinary Microbiology, vol. 105, pp. 163-167, 2005.

[26] C. Chien-Chang, S. Louie, B. A. McCormick, W. Allan Walker, and H. N. Shi, "Helminths-primed dendritic cells alter the host response to enteric bacterial infection," The Journal of Immunology, vol. 176, pp. 472-483, 2006.

[27] A. Hsiao, T. Toy, H. J. Seo, and F. Marks, "Interaction between Salmonella and schistosomiasis. A review," PloS Pathogen, vol. 12, article e1005928, 2016.

[28] L. A. Reynolds, S. A. Redpath, S. Yurist-Doutsch et al., "Enteric helminths promote Salmonella coinfection by altering the intestinal metabolome," Journal of Infectious Disease, vol. 2015, no. 8, pp. 1245-1254, 2017.

[29] H. He, K. J. Genovese, C. L. Swaggerty, D. J. Nisbet, and M. H. Kogut, "A comparative study on invasion, survival, modulation of oxidative burst, and nitric oxide responses of macrophages (HD11), and systemic infection in chickens by prevalent poultry Salmonella serovars," Foodborne Pathogens Disease, vol. 9, pp. 1104-1110, 2012.

[30] R. K. Beal, P. Wigley, C. Powers, S. D. Hulme, P. A. Barrow, and A. L. Smith, "Age and primary infection with Salmonella enterica serovar Typhimurium in the chicken influences persistence of infection and subsequent immunity to re-challenge," Veterinary Immunology Immunopathology, vol. 100, pp. 151-164, 2004.
[31] R. M. Tsoli, M. N. Xavier, R. L. Santos, and A. J. Baumler, "How to become a top model: impact of animal experimentation on human Salmonella disease research," Infection Immunity., vol. 79, pp. 1806-1814, 2011.

[32] L. Su, C. Su, W. Qi et al., "Coinfection with an intestinal helminth impair host innate immunity against Salmonella enterica serovar Typhimurium and exacerbates intestinal inflammation in mice," Journal of Infection and Immunity, vol. 82, no. 9, pp. 3855-3866, 2014. 